УДК 94(4)"1914":930

327(497.11)"1914":930

DOI https://doi.org/10.31212/tokovi.2021.3.zam.297-331

Научна критика и полемика

Примљена: 4. 10. 2021.

Прихваћена: 12.11. 2021.

John ZAMETICA

jzametica@yahoo.co.uk

\title{
The Elusive Balkan Spark: 28 June 1914, Again and Always
}

\begin{abstract}
The assassination of Franz Ferdinand on 28 June 1914 in Sarajevo justifiably continues to attract the attention of historians as one of the key events in the history of the modern world. This review essay examines several recent scholarly contributions published in a collection of essays devoted to the theme. It highlights the ongoing controversies and contradictory interpretations surrounding the subject.

KEY WORDS: Mark Cornwall, Lothar Höbelt, Andrej Rahten, Danilo Šarenac, First World War, Sarajevo Assassination, Dragutin Dimitrijević Apis, Austria-Hungary, Southern Slav question
\end{abstract}

Sarajevo 1914: Sparking the First World War, ed. Mark Cornwall. London: Bloomsbury Academic, 2020, 302.

The front cover of this book of essays, edited by Mark Cornwall, shows a well-known photograph of Archduke Franz Ferdinand and his wife, the Duchess of Hohenberg, seated in an open roof vehicle. A happy looking Archduke is shaking hands with some official. The Duchess, holding a bouquet of roses, is smiling warmly. The back cover of the book explains the historical context of the image: "Archduke Franz Ferdinand and his wife in Sarajevo, just before their assassination, June 1914."

The photograph was indeed taken in June 1914. But not on 28 June, the day of the assassination. And not in Sarajevo. It was taken on the afternoon of 2 June in Vienna, on the Hauptallee of the Prater public park, during the Blumenkorso - a jolly procession of carriages and automobiles, 
all embellished with fancy flower arrangements. Franz Ferdinand, a keen lover of flowers, was a regular visitor. The man he is shaking hands with is Gemeinderat (borough official) Gustav Schäfer, the president of the carnival committee.

It should be noted that the weather in Vienna on 2 June was not great. The photograph shows the Archduke wearing an overcoat. The weather in Sarajevo on 28 June was by contrast fine and warm and authentic photographs show him wearing a tunic. The image on Cornwall's book, which it is claimed shows a cheerful royal couple just moments before their assassination, had already been published on 7 June in Vienna's weekly Wiener Bilder. Its subsequent fame and wide circulation is due to the fact that Josef Perscheid, the photographer, saw a lucrative source of revenue after 28 June and reproduced it as a best-selling postcard. ${ }^{1}$ It is incumbent upon an author or editor to check and double check such matters as the front cover of his book. Didn't it occur to Cornwall, an expert on Austria-Hungary and an aspiring Sarajevo assassination pundit, to wonder about that overcoat? ${ }^{2}$

This might seem a petty detail, but it is typical of the way so many historians have failed to properly investigate the events of June 1914 before they then go on to err and blunder about the origins of the Great War itself. Lamentably, Cornwall's collection of essays perpetuates several of the myths and tall tales that have arisen over more than a century of historical investigation. The book contains thirteen essays written by scholars from an array of European backgrounds (as well as an introduction by Mark Cornwall). Some of the contributors are well-established and widely recognized authorities: Robin Okey, Lothar Höbelt, T. G. Otte and F. R. Bridge. Professor Cornwall himself is a noted specialist on the history of the Habsburg Empire though, oddly, his best works so far are an essay from 1995 on Serbia during the July 1914 crisis, and an earlier essay on King Nicholas of Montenegro and the Great Powers, 1913-1914. ${ }^{3}$ Saraje-

1 See: Wladimir Aichelburg, Erzherzog Franz Ferdinand von Österreich-Este 18631914. Notizen zu einem ungewöhnlichen Tagebuch eines außergewöhnlichen Lebens, Band 2: 1900-1914, (Wien: Verlag Berger Horn, 2014), 1187-1188; Wiener Bilder, Nummer 23, 7 June 1914, 5.

2 Similarly, the vehicle in which the Archduke and the Duchess are seated in this photograph is a horse-drawn carriage - on 28 June 1914 in Sarajevo they were driven in an open roof automobile.

3 Mark Cornwall, "Serbia”, Decisions for War 1914, ed. Keith Wilson, (New York: St. Martin's Press, 1995); Mark Cornwall, "Between the Wars: King Nikola of Montenegro and the Great Powers, August 1913 - August 1914", The South Slav Journal (London): 
vo 1914: Sparking the First World War has its origins in an international conference held in 2014 at the University of Southampton where Cornwall teaches. The star speaker at that conference was Professor Christopher Clark, of The Sleepwalkers fame, who, some would say regrettably, has not contributed to this volume. ${ }^{4}$

In explaining the purpose of Sarajevo 1914, Cornwall states that it is "to provide more clarity and context to an allegedly well-worn topic". This sounds quite promising. Bold claims are rarely absent from new works by historians, and indeed Cornwall states further that the chapters "bring together fresh research and thinking". This book of essays, then, according to him, offers new ways of understanding the "spark" that ignited the First World War. Thankfully, Cornwall spells out what he sees, presumably, as a main idea of the collection, namely that: "It also reasserts the importance of the Southern Slav Question as a major cause of that war". Now, this is a noteworthy claim. Observing that such a view of the Southern Slav question was something highlighted already in the 1920s, he then goes on to lament its subsequent neglect by historians, due to their "overwhelming focus on Germany." Only now, he tells his readers, are many dimensions of the Southern Slav "labyrinth" being uncovered or, indeed, "divested of their nationalist myths."

Cornwall's personal scholarly focus is thus pretty clear: let us not discuss Germany so much, let us instead concentrate on the Southern Slav question - since this matter was according to him "a major cause" of the war. And just which nation, or nations, is Cornwall anxious to see divested of its "nationalist myths"? He is not explicit here. The Slovenes, perhaps? Hardly. They played no role whatsoever in 1914. Their moment in history, albeit a narrow regional history, came as late as 1991. The Montenegrins? Not remotely. In 1914, the Montenegrins deemed Montenegro to be "the second Serbian state". They figure only sporadically on the pages of this book. The Bosnian Moslems? That would be rather improbable. Lacking a separate national consciousness at the time, most members of

Part I, Spring-Summer 1986, Vol. 9, No. 1-2; Part II, Autumn-Winter 1986, Vol. 9, No. 3-4; Part III, Spring 1987, Vol. 10, No. 1.

4 Christopher Clark, The Sleepwalkers: How Europe Went to War in 1914, (London: Allen Lane, 2012) - Clark did, however, return in the meantime, in 2017, to some of the themes covered in The Sleepwalkers with an essay in a collection published under the auspices of the German Historical Institute in London. See: Christopher Clark, "The Balkan Inception Scenario: Serbia and the Coming of War in 1914", Bid for World Power? New Research on the Outbreak of the First World War, eds Andreas Gestrich and Hartmut Pogge von Strandmann, (Oxford: Oxford University Press, 2017). 
their tiny intelligentsia considered themselves as either Serbs or Croats. They did not have a sense of their own nation, let alone any nationalist myths. Admittedly, the minarets of Sarajevo did provide on 28 June 1914 a suitably oriental backdrop for an assassination that had much to do with challenging the imperial ambitions of a western Great Power. The Croats, maybe? Out of the question, judging by the contents of these essays. The Croats certainly nourished some nationalist myths, not least the one that held Bosnia-Herzegovina to be a Croat land. Unsurprisingly, the Croats are very much present in this book given that they were at the centre of the so-called "trialist" plans, allegedly envisaged in Vienna with the aim of restructuring the dualist Austro-Hungarian Monarchy, and given also that they conceived the "Yugoslav" (South Slav) ideology - perhaps "theory" would be a better word. But there is nothing in this collection that attempts to lay bare any Croat nationalist myths.

That leaves the Serbs. In several essays of this book the Serbs living in Bosnia and Croatia are seen as the recipients of "Great Serbian propaganda". And this propaganda, of course, was assiduously directed and sustained by the independent state of Serbia, that "restless" kingdom as Cornwall describes it. The charge of nationalist mythology follows on from this familiar, sophistic premise. It is clearly reserved here for Serbian interpretations of history or, as Cornwall is keen to label them, for Serb "nationalist" historians.

The first chapter of this book contains an introduction, appropriately written by Cornwall in his capacity as editor. Appropriate, too, in the light of the collection's declared purpose, is its title: "The Southern Slav Question". However, as introductions for "students and general readers" go (Cornwall's target audience), this chapter is only likely to confuse and in some ways even mislead its readership. For, after insisting that the Southern Slav question was subject to "numerous interpretations of what it meant", Cornwall gives only a highly superficial review of this "thorny problem." His main focus is on Serbia, or rather on that little kingdom's supposed threat to the very existence of the mighty Habsburg Empire. But he does not explain how this threat actually manifested itself in the years before 1914, whether it was real or imagined, or indeed whether Serbia's national strategy had any meaningful connection with the Habsburgs' internal predicament of how to manage the aspirations of the Empire's Southern Slav populations. His implication throughout is that the Habsburg Southern Slav problem would somehow not have existed without the existence of an independent Serbia. And so we get the 
usual fare of hackneyed words and phrases that have figured for so long in so many narratives concerning the pre-1914 Austro-Serbian relations: "menace of a Greater Serbia", Serbia as "a stalking horse for Russia", the "irritating kingdom", etc. Even if we assume that such labels were factually correct, what is being ignored here is the fact that had the Habsburgs actually sought to resolve their Southern Slav problem, any Serbian peril would have been of minimal nature.

But the problem was never even addressed. Or, to be more precise, the hotheads in Vienna and Budapest thought that they could solve it by disposing of Serbia: through its military destruction first of all, and then its territorial carve-up between neighbours or outright annexation. Even today historians compete to work out the exact number of times that Franz Conrad von Hötzendorf, the Chief of the Austro-Hungarian General Staff from 1906, had proposed military action against Serbia. He finally got his opportunity in 1914. An internal political solution to the Southern Slav problem, on the other hand, was an intimidating proposition. Quite simply, for it to be attempted would have entailed a major constitutional reform of the Empire. Since 1867, however, this was never on the cards. The Austro-Hungarian Ausgleich in that year established a dualist system, paving the way for the domination of the two most numerous nations, the German-speaking Austrians and the Hungarians. The latter in particular were never going to acquiesce in anything that would even remotely threaten to diminish the power they wielded in their half of the Monarchy. István Tisza's declaration in 1911 that Hungary would fight to defend the constitution was no empty threat. The dualist system was thus set in stone: in Hungary at least, no serious reform was realistically achievable through the Monarchy's constitutional mechanisms.

Cornwall is surprisingly tight-lipped about this, in effect death warrant for any attempt to reorganize the Habsburg state so as to tackle the Southern Slav question. He does concede that the regime in Budapest "was absolutely wedded to the dualist system", but fails to consider a hugely relevant implication: that solving the Southern Slav question internally was never going to be a viable proposition without Hungary's prior political consent to the loss of some of its territory. For the Southern Slav question was to a very large extent the Croat question within Hungary. The Croats, arguably the most nationalist of the South Slavs in the Habsburg realm, happened to be living for most part under the crown of St Stephen, their lands being increasingly subjected to Magyarization. After two decades of Ban (Viceroy) Khuen-Héderváry's (1883-1903) resolute refusal to grant 
any concessions to the Croat nationalist dream based on the myth of alleged "state rights", they got another bitter taste of Hungarian ascendancy when Baron Rauch (1908-1910) governed Croatia-Slavonia by ignoring the Assembly and the Constitution. Curiously, Cornwall sees the extension of franchise in Croatia-Slavonia as evidence of Habsburg reforming endeavour. But this measure, implemented in 1910 by Rauch's successor Nikola Tomašić, concerned what was easily the narrowest electoral base in Europe: affecting only about 45000 electors out of a total population of two and three-quarters million.

Cornwall considers that the Constitution granted to Bosnia-Herzegovina in 1910 was also an example of how the Habsburg authorities had tried the reform avenue. An alternative view seems more plausible: that it was merely the end-game in a cynical imperial ploy following the annexation of 1908. The toothless Bosnian Assembly, the main gift provided by the Constitution, was created as window-dressing for a de facto colonial administration. The annexation of Bosnia and Herzegovina had highlighted Southern Slav issues not only because of Serbia's loud protests, but also because the idea of trialism appeared, to the nationalist Croats at any rate, even more alluring now that the two provinces were no longer under the Sultan's nominal suzerainty. For trialism was to them the unification of all the lands they deemed Croat, Bosnia-Herzegovina included, into a single administrative unit with its centre in Zagreb, to constitute the third entity in the Habsburg Empire. So this third body politic would be a Greater Croatia, coexisting on equal terms under the imperial Habsburg sceptre with Austria (minus Dalmatia and possibly Istria with Fiume) and naturally Hungary minus Croatia and Slavonia.

This putative realm might perhaps also be seen as a kind of Habsburg Yugoslavia, because its realization would have embraced many Serbs and all the Bosnian Muslims, and because important Slovene leaders had expressed keen interest in being included with Croatia in a trialist solution for the South Slavs of the Monarchy. A smaller version of such a Yugoslav entity had already appeared on the map of European history in the shape of Napoleon's Illyrian Provinces (1809-1814). However, what the supporters of trialism in Croatia envisaged was a Croat-led and Croat-dominated polity. Before 1914 all the major political parties in Croatia had embraced some version of trialism, but were there any Yugoslavs in their ranks, that is to say, did anyone in these parties advocate the equality as well as the unity of the South Slavs? The question is germane because no significant Croat grouping ever proclaimed a complete ethno-cultur- 
al and political identity with the Serbs, apart from when the latter were seen as an integral part of the "Croat political nation", in the spirit of the Croat state rights.

What, then, was the Yugoslav ideology all about? Principally, it was about the purported ethnic and linguistic unity of Serbs and Croats. In its more ambitious variants, the Yugoslav theory additionally embraced the Slovenes and the Bulgarians. But even such basics are barely mentioned by Cornwall. He prefers, instead, to write about the Habsburg perception of the Southern Slav question as "a fundamental threat to its existence." The truth is, however, that whereas the cultural aspect of any Yugoslav-oriented strivings was fairly clear, the political one was much less so. Was it, as Jovo Bakić asked in his study of the Yugoslav ideology, only concerned with the South Slavs of the Habsburg Monarchy? Or could it be applied, in favourable circumstances, to all the South Slavs? ${ }^{5}$ Who among the South Slavs wanted what and why? The late University of California Professor Dimitrije Djordjević, a respected Serbian-American historian, presented this subject matter lucidly when he set the idea of Yugoslavism as "an instrument of general Yugoslav" emancipation and integration against the idea of "separate national" (Serbian, Croatian, Slovene, etc.) emancipation and integration. Was Yugoslavism, he asked, "a movement or a political maneuver"? ${ }^{6}$

But Cornwall's "students and general readers" will at best only get halfway answers to such central questions from his introduction to the Southern Slav question. Admittedly, he accepts that in the decades before 1914 the Southern Slav unity had to Croat nationalists meant joining Habsburg South Slavs together into a "Greater Croatia" - trialism. Croat Yugoslavism, in other words, fits in with Djordjević's proposition about it being a "political maneuver". What, on the other hand, did the Serb nationalists dream? What were their ideas about South Slav unity? On this crucial point Cornwall does not tell us anything at all. Yet if Serbia played such a paramount role pre-1914 in developments in the south-east of the Habsburg Empire, and if Cornwall is right that the Southern Slav question was "a major cause" of the Great War, then he owes the reader a fuller treatment of that question.

$5 \quad$ Jovo Bakić, Ideologije jugoslovenstva između srpskog i hrvatskog nacionalizma 19181941, (Zrenjanin: Gradska narodna biblioteka „Žarko Zrenjanin”, 2004), 74-75.

6 Dimitrije Djordjevic, "The Idea of Yugoslav Unity in the Nineteenth Century", The Creation of Yugoslavia 1914-1918, ed. Dimitrije Djordjevic, (Santa Barbara and Oxford: Clio books, 1980), 2. 
It is at this point that some Habsburg-nostalgic historians, Cornwall among them, cease to be detached analysts and become outright proselytizers of tendentious narratives. Just exactly where Cornwall stands with regard to Serbia's foreign policy orientation before 1914 cannot be ascertained from his introduction to the book being reviewed here, but his position is clear from another text, an introduction that he wrote in 2007. This was for the English edition of Andrej Mitrović's major work Serbia's Great War, 1914-1918, first published in Belgrade in 1984. Here, Cornwall writes about the perception in Vienna of Serbia as the aggressor, "with its notorious programme of expanding and annexing South Slav territories of the Monarchy." He goes on to note that the Austro-Hungarian leaders were in 1913, i.e., just after the Balkan Wars, "determined to scotch the Serbian snake before it became an anaconda."

So we have a Serbian snake growing into an anaconda, guided by a "notorious programme" of expanding and annexing parts of the Monarchy. And while many Habsburg officials might indeed have seen a potentially dangerous animal just across the Monarchy's south-eastern border, they could not have been aware of any "programme", let alone a "notorious" one. If Cornwall is referring to Načertanije, the 1844 document somewhat falsely attributed to the Serbian statesman Ilija Garašanin, he is misleading his readers. Načertanije was indeed published in 1906, but it does not figure at all in internal Habsburg discussions up to 1914. Its notoriety is retrospective as, after the Great War, some historians began to look at it and misinterpret it. Moreover, its clear emphasis was on Serbian expansion in the territories occupied by the Ottoman Empire, not the Habsburg Empire. The idea that a pint-sized pre-1914 Serbia could seriously contemplate annexing Austro-Hungarian territories is ludicrous. That would be like, say, Mexico trying to regain Texas from the United States. True, Serbia's public and Serbian statesmen did hanker to see some Habsburg lands joined to Serbia, notably Bosnia-Herzegovina. The fact that there existed a yearning for Serb national unification presumably requires no elaboration or apology. Surely, however, historians are expected to differentiate between romantic dreams and active policy.

Indeed, the whole thrust of Serbian pre-1914 foreign policy was towards the south: Macedonia, Kosovo and an outlet on the Adriatic coast in Albania. This was a realistic course given the decrepit state of the Ottoman Empire and, as the First Balkan War showed, it was an option for

$7 \quad$ Mark Cornwall, "Introduction” to Andrej Mitrović, Serbia's Great War, 1914-1918, (London: Hurst \& Company, 2007), ix. 
which Serbia could find important regional allies. With a single exception, all the major crises between Austria-Hungary and Serbia in this period concerned issues that had absolutely nothing to do with any Southern Slav matters: the apprehension felt in Serbia (and elsewhere in the Balkans) about Vienna's role in the implementation of the Mürzsteg Agreement of October 1903; the tariff war, better known as the "Pig War", 1906-1911; and a series of crises over Albania during and immediately after the Balkan Wars, 1912-1913. The one exception was the Bosnian annexation crisis, 1908-1909. But even this episode was a peculiar exception, for Vienna's annexation of Bosnia-Herzegovina did not clash with an ongoing, vigorous Serbian policy directed at somehow seizing those lands. Rather, it clashed with Serbia's public opinion, as opposed to its government, which passionately held those two provinces as indubitably Serbian, to be united some day with Serbia. This dream was pretty much shattered by the act of annexation and hence the outrage felt in Serbia. The ending of the crisis demonstrated just how impotent Serbia was with regard to Austria-Hungary. In March 1909 the government in Belgrade capitulated, being forced to sign a humiliating document, dictated by Ballhausplatz, whereby it recognized the annexation and undertook to maintain good neighbourly relations with the Monarchy. Without a serious military capability of its own, and without support among the Great Powers, no other outcome was possible for Serbia.

Unsurprisingly, therefore, Serbia's exertion beyond its borders in the years following the Bosnian crisis focused again on the south and away from any general Southern Slav or Yugoslav matters. However, another point demonstrated by the crisis was the insistence in Serbia on a Serbian rather than a Yugoslav agenda. Even Jovan Cvijić, the famous Serbian ethnogeographer who was personally committed to the Yugoslav idea, wrote in 1909 that "Bosnia and Herzegovina are inhabited by a purely Serb race" and pleaded for the establishment of a "great Serb state." If Cornwall writes next to nothing with regard to Serbia's policy towards the South Slav parts of the Habsburg Empire it is only because there is not much to write about as far as any Yugoslav content is concerned. The best study of Serbia and the Yugoslav question remains the 1973 monograph by Dragoslav Janković. Here, Janković emphasizes that the programmes of Serbian political parties mentioned, almost exclusively, only "Serbdom". The programme of the Independent Radicals alone stipulated, rather vaguely,

8 Yovan Cvijić, The Annexation of Bosnia and Herzegovina and the Serb Problem, (London: Horace Cox, 1909), 9 and 14. 
the need to "cultivate the spirit of the Yugoslav community". Only after the Balkan Wars did Serbian politicians begin to entertain some faint notions about "narodno jedinstvo" (national unity) of Serbs and Croats, and possibly Slovenes too. However, irrespective of whether Belgrade nurtured Great Serbian or Yugoslav aspirations, the main, in the circumstances insurmountable obstacle to their fulfilment was always the existence of a powerful Austro-Hungarian Monarchy. Serbia did not pursue a policy of amputating parts of the Monarchy because that would have been suicidal. As Janković points out, Serbia was not particularly anxious to bring about unification even with Montenegro - the second Serbian state and its closest ally. ${ }^{9}$ This is something that Cornwall should be familar with, having written a fine essay on the subject. ${ }^{10}$

Try as he might to entangle and indict Serbia in his picture of the Southern Slav question, Cornwall does not convince. More than seven decades ago A. J. P. Taylor maintained that Serbia "had little interest in Habsburg lands. The Serbs aspired to liberate their brothers still under Turkish rule and to recover all the territory once historically Serb; this ambition extended to Bosnia and Hercegovina, not beyond." ${ }^{11}$ Taylor also argued that "far from Serb ambition stimulating South Slav discontent, it was this discontent which dragged Serbia into Habsburg affairs." ${ }^{12}$ The discontent to which Taylor referred began to manifest itself forcefully in the years following the Bosnian annexation crisis. A series of assassination attempts against Habsburg dignitaries was carried out, mostly by young Croats. As it happened, the most dramatic of those assassinations, that of Franz Ferdinand in Sarajevo, occasioned a massive European crisis and a world war. Cornwall correctly sees the "many youthful idealists" in the region, including the Archduke's assassin Gavrilo Princip, as embracing a Yugoslav orientation and championing Serbo-Croat unity. This is a relief if only because so many historians still talk twaddle about the Sarajevo assassins being "Serb nationalists". However, Cornwall is entirely wrong in placing Princip's ideology in the context of some "distinctly Yugoslav interpretation of trialism and the Southern Slav Question" as opposed to the Great Croatia one. For Princip was in neither sense a trial-

9 Dragoslav Janković, Srbija i jugoslovensko pitanje 1914-1915. godine, (Beograd: Institut za savremenu istoriju, 1973), see, in particular, 23-94.

10 See n. 3 above.

11 A. J. P. Taylor, The Habsburg Monarchy 1809-1918, (London: Hamish Hamilton, 1948), 228.

12 A. J. P. Taylor, The Struggle for Mastery in Europe 1848-1918, (Oxford: The Clarendon Press, 1954), 450. 
ist, being a sworn enemy of the Habsburg state, a characteristic he shared with the better part of Croatia's rebellious student youth. Yet incredibly, Cornwall lumps Princip together with a contemporary, the historian R. W. Seton Watson, who did actually support trialism as the best solution for the Empire's South Slavs. To link them on the question of trialism in this way is frankly strange.

If Cornwall is in a broad sense guilty of committing sins of omission in his introductory account of the Southern Slav question, one of the contributors to this volume is responsible for a major sin of commission. This is Andrej Rahten, a research fellow at the Slovenian Academy of Sciences and Arts. In 2014, when a flood of books appeared in connection with the 100th anniversary of the Sarajevo assassination, Rahten made his own contribution with a study of Franz Ferdinand in the light of Slovene interpretations of the assassination. He had previously also produced an interesting study of contemporary Slovene perceptions of the Balkan Wars. ${ }^{13}$ His piece in Cornwall's collection (entitled "Great expectations: The Habsburg heir apparent and the Southern Slavs") draws heavily on the research presented in those books.

In his essay Rahten resolutely supports two related contentions: that Franz Ferdinand and his military chancellery in Vienna's Belvedere palace were seriously planning a major constitutional reform of the Monarchy, that is, a trialist re-arrangement to accommodate the Southern Slavs; and that the Archduke's assassination was the direct consequence of the dismay felt in Serbia that such a trialist adjustment would be at the expense of its competing scheme for a Greater Serbia. This line of argument is hardly new. But Rahten is very determined to develop it. Right at the beginning, he confidently asserts that the real power of the Belvedere circle "was hidden in the reform plans for the creation of a Southern Slav unit within the Habsburg Monarchy, which might be able to undermine aspirations to create Greater Serbia. Therefore, the story about the motives for the assassination of the Habsburg archduke is also a study of the concepts for reconstructing Austria-Hungary."

13 Andrej Rahten, Prestolonaslednikova smrt: po sledeh slovenskih interpretacij sarajevskega atentata, (Ljubljana: Cankarjeva založba, 2014); Andrej Rahten, Jugoslovanska velika noč: Slovenski pogledi na balkanski vojni (1912-1913) in jugoslovansko vprašanje, (Ljubljana: GV Založba, 2012). 
This must have been extraordinarily well "hidden". For, interestingly, Rahten is unable to refer to a single Belvedere plan for reconstructing the Empire so as to create a Southern Slav unit within it. And the one document from the Belvedere that he does mention contains no scheme for establishing a South Slav component - in fact it actually points out the dangers of such trialism. This is the 1911 programme for Franz Ferdinand's accession (Programm für den Thronwechsel), which in reality just set out an agenda for downgrading the status of Hungary in order to make possible the Archduke's chief political aim: a Monarchy run from Vienna or what he and his acolytes called Gross Österreich. ${ }^{14}$ Far from planning to fragment the state structure even further through some trialist project, Franz Ferdinand and most of his Belvedere circle wished to do away with dualism so as to erect a centralized, dynastic and Austrian-dominated Empire.

Lacking any direct evidence of plans for the construction of a South Slav entity, Rahten resorts to second-string tactics to argue his point. He admits that Franz Ferdinand was no Slavophile, favouring the "culturally superior Germans". He also accepts that Great Austria was the Archduke's main objective. Without any supporting materials, however, he maintains that a constitutional reform through trialism was how the Belvedere circle envisaged the attainment of the ideal of Great Austria: "On the one hand, concessions would be made for dividing the state into three major units [...] and on the other, a strong centralized government and parliament would simultaneously be created in Vienna for all provinces of the Monarchy. Each of the three state units of the Monarchy would then further be divided into smaller crown lands and all nations would be ensured some autonomy in national and cultural matters." This was the way, Rahten insists, to weaken Hungary, dismantle the dualist system and simultaneously build strong central institutions in Vienna.

Rahten is of course right that Franz Ferdinand was bent on destroying dualism. But everything that we know about his post-accession plans suggests that he would have dealt with Hungary without recourse to trialism. The Thronwechsel programme advocated the imposition of universal suffrage on Hungary as a means of breaking the power of the Hungarian gentry, and even envisaged the use of military force. The mindset of the Archduke and some of his closest associates, beginning with Alexander Brosch, the head of the Belvedere chancellery, hardly suggested a proclivity for pacific constitutional tinkering. Ottokar Czernin, both

14 See: Georg Franz, Erzherzog Franz Ferdinand und die Pläne zur Reform der Habsburger Monarchie, (Brünn-München-Wien: Rudolf M. Rohrer, 1943). 
a friend and adviser of the Archduke, urged him in 1909 to enforce his policy in Hungary "with bayonets". The Archduke himself was reported as saying that, if necessary, he would combat dualism with "blood and iron". ${ }^{15} \mathrm{He}$ never said that he would combat it with trialism. Rahten, nevertheless, writes that "key figures" in the Archduke's circle backed trialism as a means of establishing Great Austria - but he does not name any of them. In fact, quite a few of those key advisers are on record as opposing trialism. For example, Paul Samassa and Theodor von Sosnosky argued against it. More importantly, the men who were in charge of Franz Ferdinand's military chancellery at the Belvedere, Brosch and his successor Karl Bardolff, were highly sceptical. Both doubted the wisdom of trialism not least because the South Slavs could not be seen as necessarily loyal to the Crown. ${ }^{16}$

This position, incidentally, was shared by the Archduke himself. The point about the questionable fidelity of the South Slavs is important here. Franz Ferdinand did, in 1903 when he was politically still inactive, express support for trialism. But in 1905 he was shocked when the Croats and the Serbs of Croatia concluded an alliance in the aftermath of the famous Fiume and Zara resolutions, supporting Budapest in its independence drive against Vienna. Thereafter he would on the whole only mention trialism as a useful tactic to unnerve the Hungarians. Rahten, however, is adamant that, "irrespective of the occasional doubts about Croatian loyalty [...] Franz Ferdinand seems never to have completely abandoned his trialist plans." By contrast, Rudolf Kiszling, Franz Ferdinand's de facto official biographer, noted that after the Fiume and Zara resolutions the Archduke's trialist plans had "noticeably faded in so far as they had taken any firm shape in the first place." ${ }^{17}$

15 John Zametica, Folly and Malice: The Habsburg Empire, the Balkans and the Start of World War One, (London: Shepheard-Walwyn, 2017), 64-65.

16 Ibid., 92-93.

17 Rudolf Kiszling, Erzherzog Franz Ferdinand von Österreich-Este. Leben, Pläne und Wirken am Schicksalsweg der Donaumonarchie, (Graz-Köln: Böhlau, 1953), 121122. - In his essay, Rahten does not mention a draft letter by Franz Ferdinand to Wilhelm II from July 1909 in which the Heir to the Throne calls trialism "ein Unglück" (a "tragedy" or "calamity"). But he addresses this, for him uncomfortable document, in his 2014 book on Franz Ferdinand. The latter, he argues, was not referring to the state-constitutional unity of the South Slavs, he was merely warning of the danger posed to the Germans of the Monarchy by the Slavs through Pan-Slavism, and by the Hungarians through their chauvinism. In other words, to counteract inconvenient evidence Rahten creates an additional and quite absurd definition of trialism as a general, three-way racial division of the Habsburg Empire. See: Rahten, Prestolonaslednikova smrt, 133-136. 
In fact there is no stopping Rahten on his neo-trialist crusade. Anxious to produce clinching evidence that Franz Ferdinand was serious about trialism, he refers to a 1930 "book" (in fact a booklet, 86 pages long) by one Edmund von Horváth, a Habsburg diplomat of Croatian descent, to whom he attributes "superior knowledge of Serbia" and describes as "undoubtedly a go-to expert in discussions on the Southern Slav Question." ${ }^{18}$ This is odd, given that Horváth is conspicuous by his absence in the relevant Austrian memoir literature. The massive, eight-volume official collection of Austro-Hungarian documents for 1908-1914 (Österreich-Ungarns Aussenpolitik) contains not a single report, letter or memorandum from him, something that can easily be checked in the Personenregister accompanying the collection.

Be that as it may, this indispensable expert on the Southern Slavs was in April 1914 serving in Munich when Franz Ferdinand was in town, visiting the Bavarian Court. Rahten relates the account by Horváth that the Archduke had invited him for a discussion of South Slav problems which he thought required an immediate solution as they constituted the Monarchy's "most critical domestic and foreign political issue." He talked about the resistance of Hungary to the settlement of the Southern Slav question, remarking that, in the worst case, Hungary would have to give up Croatia and Slavonia; Austria, on the other hand, would have to give up Carniola (Slovenia), Istria and Dalmatia, thus making the greater sacrifice. The Archduke was keen to stem the "Serbian flood" and even suggested erecting, on the model of Maria Theresia, a military frontier from Zemun on the Danube to Kotor on the Adriatic in order to block a Serbian "invasion". As for the Southern Slav unit, he said its capital would be in Zagreb and considered that it would easily fit into the constitutional structure of the Monarchy. Rahten concludes triumphantly: "This was only two months before his death in Sarajevo."

The first thing to note here is the curious fact that, until Rahten came along, no historian dealing with the subject matter of South Slav trialism appears to have spotted, or used, Horváth's testimony - available since 1930. Rahten singles out one of those sloppy historians: Vladimir Dedijer, the author of The Road to Sarajevo, a classic account of the 28 June 1914 assassination. He writes: “Interestingly, Dedijer's impressively comprehensive list of sources and literature did not contain a book by Edmund von Horváth". It is of course not surprising that Rahten should

18 E. v. Horvath, So starb der Friede. Unbekanntes über die Entstehung des Weltkrieges, (Berlin: Brückenverlag, 1930). 
berate Dedijer for ignoring Horváth since Dedijer is a well-known sceptic with regard to Franz Ferdinand's alleged South Slav trialist agenda. But it is interesting that Rahten is unable to assist his Horváth case by cross-reference to the work of some historian from among those who have famously championed the South Slav trialist thesis. Say Luigi Albertini. The latter's sources are even more impressive than Dedijer's, and yet somehow he neglects Horváth's startling account.

Which inevitably raises the question of Horváth's credibility. Would Franz Ferdinand seriously have contemplated that Serbia, a minor military power, could ever stage an "invasion" of Austria-Hungary? And would he, a man well versed in modern military matters, have earnestly suggested an $18^{\text {th }}$ century type of defence? Was Franz Ferdinand in April 1914 really in such a generous frame of mind as to sacrifice Carniola, something that would have cut off the all-important port of Trieste from Austria and in a wider sense from the Germanic world? Was he genuinely willing to give up Istria where the Austro-Hungarian navy, of which he was the greatest protector and champion, had its main port at Pola? Was he actually so charitable as to forfeit Dalmatia, a major strategic asset, important equally for the navy and the merchant fleet? Regarding Dalmatia, in 1907 he raged against the aspirations of Croat politicians for joining the province with Croatia-Slavonia. Those aspirations, he insisted, had to be "crushed". ${ }^{19}$ What exactly could have changed his outlook since 1907? Most of all, what could have caused him to suddenly cease doubting the loyalty of the Croats and other South Slavs?

Highly unlikely as Franz Ferdinand would have been in 1914 to fear an invasion by Serbia, or willing to surrender valuable Austrian-ruled territories for the sake of creating a South Slav unit within the Empire, can the testimony presented by Horváth simply be discounted? The answer is yes as there exists a solid reason why his booklet has been ignored, and it is provided by Horváth himself. In the concluding section he refers to the speech by Stephen Pichon, the French Foreign Minister, at the opening of the Paris peace conference. In that speech, Horváth writes, Pichon talked about the "mysterious murder" at Sarajevo. The meaning of that remark, he continues, was that the assassination was "ordered and arranged" by Austria-Hungary so that it could have a moral excuse to attack an innocent Serbia. Only a few weeks after the speech, however, this "monstrous accusation" was publicly disproved since, according to Horváth, at the end of the war "the murderers who were imprisoned in Theresienstadt in Bo-

19 Zametica, Folly and Malice, 90. 
hemia were freed, arriving in Prague amid great celebrations and accompanied by enormous jubilation of the populace; Princip, one of the leaders, explained that he claimed for himself and his comrades the glory for initiating the liberation of enslaved peoples through the deed that he exalted with rousing words." ${ }^{20}$

This breathtaking report of the ressurrection of Princip and comrades to the acclaim of crowds in post-war Prague must surely be sui generis since resurrecting dead people is not something that chroniclers of events are known for. Rahten is curiously silent on the fact that Horváth's story is entirely fictitious. The three assassins who were imprisoned in Theresienstadt all died there during the war: Nedeljko Čabrinović and Trifko Grabež in 1916, and Gavrilo Princip in April 1918. Horváth has zero credibility and his report about meeting with Franz Ferdinand is consequently worthless. And it defies belief that Rahten, having tried to make use of such a spurious source has the audacity to reproach a renowned historian like Dedijer for not doing the same.

Rahten then proceeds to elaborate the argument that it was precisely the Archduke's trialist reform plan that had led people in Serbia to arrange for his assassination. He is by no means the first historian to have pushed this theory. Its most famous exponent is Luigi Albertini, on whose monumental study of the origins of the war of 1914 generations of historians have relied. In preparing his work, Albertini had talked to Apis's nephew Milan Živanović. Already at that time, in the 1930s, Colonel Dragutin Dimitrijević Apis was being widely credited for masterminding the Sarajevo assassination. Živanović assured Albertini that the Archduke "fell victim of his political views favourable to trialism." Had he succeeded in carrying through his design, Živanović said, "Serbia would have ended by gravitating towards Austria-Hungary." And that is why, according to Živanović, Apis "decided to seize the first occasion to eliminate Francis Ferdinand." ${ }^{11}$

20 Horvath, So starb der Friede, 85. The passage in German: "Schon wenige Wochen nach dieser Rede wurde diese ungeheuerliche Anschuldigung in aller Öffentlichkeit dementiert; denn als nach dem Umsturz die in Theresienstadt in Böhmen in Haft befindlichen Mörder freigelassen wurden und in Prag unter großen Feierlichkeiten, begleitet von riesigen Jubel der Bevölkerung, einzogen, erklärte Princip, einer der Führer, daß er für sich und seine Genossen den Ruhm in Anspruch nehme, durch die Tat, die er in schwungvollen Worten verherrlichte, die Befreiung der unterjochten Völker eingeleitet zu haben."

21 Luigi Albertini, The Origins of the War of 1914, vol. 2, (London: Oxford University Press, 1952), 87. 
But how trustworthy is this close relative of Apis? His 1955 book on Apis is pure apologia. ${ }^{22}$ Unsubtly and unbecomingly, he described his uncle to Albertini as "an acute political thinker". Would Apis, one might ask, have shared his political views with a very young person? Živanović was barely eighteen years old when Apis was executed in 1917. Furthermore, not a single of Apis's contemporaries who recorded his utterances on the assassination in Sarajevo ever related anything about him expressing a view on trialism. As is well known, at his 1917 trial Apis wrote a confidential report in which he talked about eliminating Franz Ferdinand as the leader of the military party preparing to attack Serbia. In 1914-1915, similarly, he was telling his fellow Army officers that the Austro-Hungarian maneouvres attended by the Archduke would lead to an invasion of Serbia and hence he organized the assassination. How likely is it that the teen Živanović would be the only person to have heard Apis tell a somewhat different story?

But Rahten does not rely on Albertini or Živanović. No, he relies on Apis himself. True, he does dwell somewhat on the unease about trialism expressed by the Serbian diplomat Miroslav Spalajković and Prime Minister Nikola Pašić. But he is careful enough not to accuse them of playing a part in the Sarajevo assassination. Instead, he cites Apis himself: "By uniting South Slavs of the Monarchy under a uniform, co-ordinated administration [trialism], the archduke might halt the erosion of Austrian power and envelop Serbia." Rahten writes that Apis made this statement about Franz Ferdinand "later", in order to "justify the terrorist methods of his organization." What a bombshell. There we appear to have, from the horse's mouth, the definitive explanation for the start of the First World War. However, there is a small problem. Rahten does not tell us anything about the context of Apis's statement. Who recorded it and where? Who was the person who heard it, and exactly when ("later") and where was it supposed to have been made?

Thankfully, Rahten does have a corroborating footnote for Apis's statement. This is a book by one Tony Fabijančić. ${ }^{23}$ Now, few historians have heard of this Canadian academic (he teaches English) and travel writer of Croatian descent. Eccentrically, he is Rahten's source. Glancing at the relevant page of his book, everything looks proper at first: Rahten has cor-

22 Milan Ž. Živanović, Pukovnik Apis: solunski proces hiljadu devetsto sedamnaeste, (Beograd: izdanje pisca, 1955).

23 Tony Fabijančić, In the Footsteps of Gavrilo Princip, (Edmonton: The University of Alberta Press, 2010), 62. 
rectly cited from Fabijančić. But is Fabijančić citing Apis? Well actually no, he is not. Just like Rahten, he provides no context, although it is clear that he is citing someone else's thoughts. Thankfully again, the Canadian has given a footnote. This is David MacKenzie's 1989 biography of Apis. ${ }^{24}$ One wonders, therefore, why Rahten is not using MacKenzie's well known, if somewhat erratic work on Apis, preferring instead the obscure book by Fabijančić. MacKenzie is accurately cited by Fabijančić, though "trialism" in square brackets is Fabijančićs own addition, reproduced by Rahten. So does MacKenzie cite Apis? No. Mackenzie does not put the statement given in Rahten into Apis's mouth: he uses no quotation marks. This is the crucial point. And whereas the amateur historian Fabijančić likewise does not attribute the statement to Apis, the professional historian Rahten has Apis as the author of those remarks. MacKenzie also fails to provide the context, but his fuzzy account comes across as being possibly his own interpretation of Apis's line of reasoning regarding Franz Ferdinand's trialist intentions. Alternatively, Mackenzie is merely relating someone else's commentary on that subject.

Thankfully yet again, MacKenzie also gives a footnote. This refers to two items from the papers of the aforementioned Živanović, deposited at the Serbian Academy of Sciences and Arts..$^{25}$ In the relevant section of his book, MacKenzie combines material from both. Reading these items the critical fact is clear: Živanović is not citing Apis but merely hypothesizing about Franz Ferdinand's intentions towards the South Slavs. The Heir to the Throne, according to Živanović, wished to consolidate the Monarchy by transforming it into "a union or federation of independent national states, joined together under the Habsburg Crown, with a central parliament and several ministries for joint affairs." The South Slav question was meant to be solved by uniting the Yugoslavs under the Habsburgs. This plan, Živanović continues, would result in "the collapse of all prospects for the liberation and unification of Yugoslavs in an independent state. For

24 David MacKenzie, Apis: The Congenial Conspirator, (Boulder: East European Monographs, 1989), 124-125.

25 Arhiv SANU, Zaostavština Milana Ž. Živanovića, 4019: "Rad organizacije Ujedinjenje ili Smrt"; 719: "Konflikt 1914. godine". These items are typewritten, but undated and richly sprinkled with handwritten interventions by Živanović. Almost certainly, the first one was a lecture or a talk since Živanović employs a public speaking manner of address. 
Serbia, it would mean the end of its independence." Hence Apis and comrades resolved to eliminate Franz Ferdinand as the "immediate threat". ${ }^{26}$

And whereas Živanović told Albertini that Franz Ferdinand had been pushing trialism, he talks here about federalism. But such niceties do not matter. The bottom line is that Živanović - Apis's "worshipful nephew" as MacKenzie calls him - indulges in making personal and wholly unsubstantiated observations. ${ }^{27}$ Accordingly, if anyone wishes to fully check the veracity of Rahten's sensational revelation that Apis himself had explained the Sarajevo assassination as his response to Franz Ferdinand's trialist plans, the road is convoluted and tough, to put it mildly. A doubting Thomas will first need to obtain a copy of Fabijančić's little known book as this is Rahten's bizarre source. He will then have to look up MacKenzie's admittedly standard work on Apis. But then, as the last step, he will have to travel to Belgrade to inspect MacKenzie's source in the archive. Scarcely any of Cornwall's "students and general readers" are likely to make even the first step. Only some very persistent specialist would be keen to go all the way to track down what turns out on inspection to be a major falsehood. Rahten's essay, certainly, is not a worthy specimen of what Cornwall advertises as "fresh research and thinking" in his collection.

In highlighting Franz Ferdinand's alleged trialist plan as the reason for his assassination, Rahten has merely recycled an old conspiracy theory. Which is why the title of another of the essays in Cornwall's collection sounds very promising: "Why did nobody control Apis? Serbian military intelligence and the Sarajevo assassination". The author is Serbian historian Danilo Šarenac whose 2014 book on Serbia and the First World War combines straight historical themes, military-technical matters (especially concerning guns), and the currently fashionable excursions into the culture of war remembrance. ${ }^{28}$ His essay in this collection is praised by Cornwall in a letter to The Times Literary Supplement for providing "balanced research" ${ }^{29}$ Trouble is, there is almost no research in Šarenac's contribu-

26 Arhiv SANU, Zaostavština M. Ž. Živanovića, 4019: “Rad organizacije Ujedinjenje ili Smrt", 9-10.

27 MacKenzie, Apis, 126.

28 Danilo Šarenac, Top, vojnik i sećanje: Prvi svetski rat i Srbija, 1914-2009, (Beograd: Institut za savremenu istoriju, 2014).

29 'The Habsburgs', Letters to the Editor, The Times Literary Supplement, 31 July 2020. 
tion: he tells us nothing new about either Serbian military intelligence or the Sarajevo assassination.

Šarenac himself writes that "no new sources are available" for his topic. Why bother, then, with this cobbling together of yet another account of the links between Serbia and the assassination of Franz Ferdinand? But lack of new evidence has never stopped a self-respecting historian, and indeed Šarenac hastens to add that "a more detailed analysis of the domestic Serbian social-political context can help us understand better the role of official and unofficial Belgrade in the Sarajevo plot." Specifically, the terrain he wishes to explore is that of civil-military relations in pre-1914 Serbia. He acknowledges that this subject has already been scrutinized by historians, but only "partially". ${ }^{30}$ Due to the "complexity" of the domestic civil-military conflicts, he maintains, "much remains unresearched and unclear."

Unfortunately, rather than addressing this, Šarenac proceeds to rehash some of the all-too-familiar, well-researched themes: the political, economic and cultural rise of the Serbian society following the violent change of dynasty in 1903; the persistent political influence thereafter of Army officers associated with the coup; the long running affair regarding the proposed procurement abroad of modern artillery; the Austro-Serbian tariff war: the annexation of Bosnia-Herzegovina; the Balkan Wars; and, of course, the emergence in 1911 of a conspiratorial organization popularly known as "Black Hand". And if Šarenac adds absolutely nothing original to any of this, at least he feels the need to acknowledge that 1903 was not the watershed year as far as Serbia's foreign policy was concerned - a welcome statement given that so many historians have falsely interpreted the murder of the last Obrenović king as ushering in an aggressively nationalist and even pro-Russian course, all of which supposedly culminated in the Sarajevo assassination.

A good deal of Šarenac's essay is contained in the section entitled "The network of Serbian military intelligence". What is remarkable here are his allusions that routine intelligence activities conducted by Serbian officers amounted to some kind of misconduct or wrongdoing. For example, in building up his dossier of such activities, Šarenac discloses in all se-

30 Šarenac lists the following works: Dušan T. Bataković, "Storm over Serbia: The Rivalry between Civilian and Military Authorities (1911-1914)", Balcanica, (Belgrade), vol. 44, 2013; Vojislav J. Vučković, "Unutrašnje krize Srbije i Prvi svetski rat", Istorijski časopis, (Beograd), vol. 14-15, 1963-1965; Radovan M. Drašković, Pretorijanske težnje u Srbiji. Apis i „Crna ruka“, (Beograd: Žagor, 2006). 
riousness the astonishing fact that the Serbian military were keen to obtain "maps of the Turkish border regions". In a similarly breathless tone he refers to the Russian Chargé d'Affaires in Belgrade Vasily Strandtmann recalling in his memoirs that "Serbian agents" had in 1911 sent reports about the concentration of Austro-Hungarian forces along the border of the Sanjak of Novi Pazar. One is compelled to ask: so what? Is Šarenac perhaps suggesting that Serbia's military intelligence service should not have been collecting military intelligence? But that was its job. At any rate, it is with such "bits and pieces of the surviving sources", as he puts it, that he wishes to prove how Serbian military intelligence was "very active", especially in Bosnia-Herzegovina.

With regard to the latter, moreover, Šarenac insists that in those provinces Serbian intelligence had been very much alive even before Apis became its head in August 1913. He therefore questions Apis's subsequent testimony to the contrary. He cites Apis as stating, at his Salonika trial in 1917, that on taking on his new job he "found almost no organization in Bosnia." But that is not at all what Apis said. He actually said: "I found no organization whatsoever" ("nisam zatekao nikakvu organizaciju"). He did not specify Bosnia, he was more extensive since he talked of his intention to develop an intelligence service "on the territories of interest to us" ("na teritorijama koje su nas interesovale"). And he did not say "almost" - this is another addition by Šarenac, one which surely cannot inspire trust in his use of sources. Apis had been categorical that no organization existed. ${ }^{31}$ Šarenac argues that Apis was merely relating his frustration at not finding any "high-profile agents". This actually sounds plausible and it begs the question why, in that case, has Šarenac tampered with the words of Apis in the first place. Of course there existed a Serbian intelligence gathering effort. The fact that military activities across the western border would have been monitored by Belgrade before 1913 requires no particular emphasis in the light of the contemporaneous Austro-Hungarian mobilizations during the Balkan Wars and indeed in the light of the tensions prevailing since the Bosnian annexation crisis.

Much of what Šarenac brings up has to do with pretty mundane operations: reports of movements of troops, contacts with agents and civilians, transports of messages from Serbia to confidants in Austria-Hungary, etc. But he also highlights the institution of the Officers Border Service, established in 1911 to enhance intelligence work in the frontier areas.

31 See the source used by Šarenac: Borivoje Nešković, Istina o solunskom procesu, (Beograd: Narodna knjiga, 1953), 170. 
What Šarenac is keen to show here is that all the officers assigned to those posts were members of Black Hand, enabling Apis to manipulate politically with sensitive data. Having thus shifted his focus somewhat away from Serbia's spying on Austria-Hungary to the domestic political scene, he misses an opportunity to make a much better case about Apis's appetite for making trouble at home. For he omits to explain that Radovan Drašković, on whose work he otherwise relies here, gives a rather different reason for the existence of the Officers Border Service. Drašković argues that the chief task of those officers was in fact to recruit supporters in Austria-Hungary under the pretext of patriotic enterprise, giving them military training in Serbia but then keeping them there to be used as a reliable force "at a decisive moment" during a domestic political overthrow. ${ }^{32}$

Šarenac's purported main theme, "Serbian military intelligence and the Sarajevo assassination" - the subtitle of his essay - merits barely three pages. Yet it is replete with factual errors and fanciful claims. A good example is his assertion that Apis knew of Franz Ferdinand's planned visit to Bosnia as early as September 1913, thanks to Rade Malobabić, his chief operative in Austria-Hungary: "That information had been released in March [1914], but Apis knew about it already in September 1913". What an intelligence coup by Malobabić that must have been, for in September 1913 not even Franz Ferdinand himself knew that he would be going to Bosnia the following summer. He only gave his assent to attend the manoeuvres in February 1914. ${ }^{33}$ Šarenac does not provide his readers with evidence for his earlier timeframe.

Given that his essay pretends to offer new perspectives on the linkage between Serbian intelligence and the Sarajevo assassination, it is a tad excruciating to read the tired old stuff that Šarenac trots out. All the hackneyed keynotes are there: three Belgrade-based students from Bosnia (Princip, Grabež and Čabrinović) like visiting local pubs where they approach some unemployed Balkan Wars veterans, asking them for weapons; a contact is eventually established with Major Tankosić, Apis's righthand man; Tankosić is reluctant to help, but after persistent demands by the youths he talks to Apis; the latter gives free rein to Tankosić even though he knows that the target is Franz Ferdinand; weapons are handed to the students who are then helped to get across into Bosnia by military personnel on the border; when Apis informs other members of Black

32 Drašković, Pretorijanske težnje, 145.

33 Gerd Holler, Franz Ferdinand von Österreich-Este, (Wien-Heidelberg: Verlag Carl Ueberreuter, 1982), 174. 
Hand about the operation they object and Apis apparently tries to stop it but is unsuccessful - etc., etc.

This basic narrative has been endlessly recited for many years. Its central assumptions are that Tankosić notified Apis about the students' assassination plan, and that his boss gave the green light. But there is precious little evidence for this, and such evidence as has been paraded is hugely problematic. ${ }^{34}$ Šarenac himself puts it well: "It is true that all evidence linking Apis to the conspiracy is loose and circumstantial." However, this does not deter him from endorsing the above story line. And he disputes the recently expounded judgement that Apis was initially unaware of the assassination plot, its organization being an entirely private enterprise of the wayward Major Tankosić. According to Šarenac, "it is hard to imagine that Apis, who was powerful enough to approve the appointment of so many Serbian ministers of war, was not able to control one Serbian major". However, while historians invariably find many things "hard to imagine", this one regarding Tankosić is not a bit unimaginable: his recklessness, insubordination and proactive daredevilry has been extremely well documented by many sources.

Why is Šarenac so keen to keep Apis as the cardinal player in the Sarajevo assassination story? He helpfully offers the answer: "To exclude Apis from the Sarajevo assassination plan [...] would mean seriously to ignore the entire Serbian pre-1914 context." Except that Šarenac does not understand this context. Having pointlessly bombarded his readers with unremarkable examples of Serbian military intelligence activity, he zooms in on spring of 1914 when a major crisis occurred in civil-military relations. This had to do with the so-called "Priority Decree", an attempt by the Serbian government to assert the primacy of civilian over military authorities on the new territories gained in the Balkan Wars. The whole affair has been thoroughly researched elsewhere. But it had nothing to do with either military intelligence or with the organization of Black Hand as such. What cannot be denied is that at this time of hightened tensions Apis was preparing a putsch, intending to inaugarate military rule in the country. When, however, he sent instructions for the commencement of the coup, his fellow officers, members of Black Hand, flatly refused to act. Lo and behold, Serbian officers actually stood up in defence of the constitutional order. Šarenac describes their rebuff of Apis as "strange". In reality, as these events showed, what the famous Serbian militarist, "Praetorian" clique amounted to in 1914 was just Apis and a few blindly loyal

34 For details, see: Zametica, Folly and Malice, chapters 11-12. 
Black Hand members such as Major Ljubomir Vulović. Oddly, earlier in his essay Šarenac himself admits that Apis was not really "so powerful", and that the crisis of spring 1914 "showed this very well."

In painting his picture of strained civil-military relations in Serbia, Šarenac is on more relevant ground when he refers to the complaints by Serbian civilian authorities in the areas adjoining Bosnia about the conduct of local Army officers in June 1914. Again, this episode was researched by Vladimir Dedijer as long ago as $1966 .{ }^{35}$ Serbian officials on the ground had alleged that Army officers had overseen the transport of arms across the border into Bosnia. Anxious about possible repercussions for relations with Austria-Hungary, the government of Nikola Pašić in Belgrade investigated the case. In a report he wrote on 21 June Apis admitted that he had given his chief spy Malobabić four revolvers, but only for the purpose of self-defence of Malobabić's couriers and confidants, and he complained about the interference of Serbian police with Army activities. ${ }^{36}$ This incident, indeed, speaks something of the problematic nature of civil-military relations in Serbia, but to argue, as Šarenac does, that in June 1914 Serbian officials and Army personnel in the frontier area "were on the verge of a full-scale conflict" is surely an exaggeration, investing the matter with a degree of drama that simply was not there.

Towards the very end of his essay, Šarenac finally spells out what his discussion was meant to demonstrate: "The Sarajevo assassination can therefore be seen as one episode in the domestic power struggle between the Serbian government and the military." Just like that. Sensing perhaps that this will not do, he offers a speculative explanation why Apis had made "welcome arrangements for the Archduke". The idea behind the assassination plot, he suggests, was not to assassinate, rather it was "specifically calculated" to harm Pašić's government by creating yet another difficulty with the Austrians: "By adding his support to a group of young men aged sixteen to twenty who had never before shot at any live target, Dimitrijević was setting the stage for a diplomatic scandal rather than trying to provoke a Serbian-Austrian war."

35 Vladimir Dedijer, The Road to Sarajevo, (London: MacGibbon \& Kee, 1967), 390392. For a much more detailed treatment, see Dedijer's revised account: Vladimir Dedijer, Sarajevo 1914, vol. 2, (Beograd: Prosveta, 1978), 111-121. For a more recent analysis, see: Mile Bjelajac, 1914-2014: Zašto revizija? (Novi Sad: Prometej, 2019), 59-74.

36 Those four revolvers were Nagans, not to be confused with the four Browning pistols carried by the Sarajevo assassins. See: Bjelajac, 1914-2014: Zašto revizija?, 69-70. 
This, then, is apparently Šarenac's "new light on the Serbian political-military power struggle of 1914" that Mark Cornwall is enthusing about. ${ }^{37}$ Except that it is neither new nor in the least enlightening. Writing his work on Apis and the Black Hand in the 1960s, Radovan Drašković was the true author of this conjecture concerning the motive behind the assassination plot. Apis, Drašković suggested, may have believed that absolutely no harm could come to the Archduke as he was so well protected; the assassins, nevertheless, were bound to try something, and that would suffice for Austria to get incensed and demand satisfaction from Serbia once it became established that the offenders had come from that country; given that Austria deplored the Russophile orientation of Pašić's Radical Party, it would demand the removal of the government and of the Radicals in general. ${ }^{38}$

Here, Šarenac does not acknowledge Drašković whose work he nonetheless exploits in different contexts. At any rate, unlike Šarenac, Drašković implicitly rejected his own theory about the assassination plot. He referred to a well-known 1915 statement by Apis that, when he approved the action in Sarajevo, he thought it would be impossible for it to succeed or even take place. Drašković commented: "To send people with four revolvers and six bombs across the border with the task to kill the Austrian Heir to the Throne, and then to console oneself that they would nevertheless not be in a position to carry out the deed is, to put it mildly, laughable." ${ }^{39}$ Indeed. Historians are understandably keen to generate interest in their specific fields of study, they feel obliged to churn out papers on the anniversaries of historical events, and they rather like going to international conferences to present their work. But we could and should have been spared this effort by Danilo Šarenac.

In sharp and welcome contrast, there are several essays in Mark Cornwall's collection that give a powerful impression of reliability, quality and authoritative judgement. Such, for example, is the piece by Robin Okey: "Mlada Bosna: The educational and cultural context". Okey is the author of a major study of the Habsburg "civilizing mission" in Bos-

37 'The Habsburgs', Letters to the Editor, The Times Literary Supplement, 31 July 2020.

38 Drašković, Pretorijanske težnje, 193.

39 Ibid., 197. 
nia-Herzegovina, unsurpassed for its depth of scholarship. ${ }^{40}$ In this essay, he is principally concerned with highlighting the different roots of the anti-Habsburg revolt by Bosnia's student youth, loosely grouped in a movement that became known as "Young Bosnia". He emphasizes the "colonial aspect" of the Austro-Hungarian occupation of Bosnia-Herzegovina which inevitably produced psychological alienation between largely uneducated locals and foreign officials. The sense of being "second-class citizens in their own land" was hardly abated by the fact that the educational system produced paltry numbers of native administrators, and then only in the lowest ranks. Okey discusses four mainsprings for the phenomenon of Young Bosnia: (1) the progressive ideas received via Bohemia and Croatia; (2) the Balkan traditions of resistance; (3) the ideas of revolutionary socialism, of Russian populism and anarchism, and of radical philosophers such as Nietzsche; and (4) the Yugoslav idea which was in fact a revolutionary creed and which was "winning out in the immediate backdrop to the Sarajevo assassination." These themes are developed by Okey with an enviable elegance and grasp of relevant detail. He gives an interesting example of how Habsburg officialdom refused to recognize what was happening with the Bosnian students. A report in 1912 pointed out the autonomous character of the nationalist youth, arguing that the nationalist elders were not controlling it and were in fact distrusted. The report was then "quietly filed away."

Okey also makes comparisons and finds parallels between Young Bosnia and other, colonial-context interactions between natives and foreign rulers, among others in India and in Egypt under Lord Cromer. He draws attention not only to the dialectic between the attraction of modern ideas and the loathing of foreign rule, but also to the foreign rulers' convenient rationalization of their rule over others as an undertaking "on behalf of progress". Such claims of legitimacy pertained very much to Habsburg-ruled Bosnia-Herzegovina, where the occupiers regarded the native population "in many ways like other non-European populations of the age." Reading Okey's essay, one cannot help making the correlation that Kipling's "white man's burden", in this case the Habsburgs' burden, paradoxically involved even some white people in pre-1914 Europe.

Another virtuoso contributor to this collection is Lothar Höbelt, Professor of modern history at Vienna University. Among Höbelt's many works, perhaps the outstanding one is his 2015 study of Austro-Hungarian

40 Robin Okey, Taming Balkan Nationalism: The Habsburg 'Civilizing Mission' in Bosnia, 1878-1914, (Oxford: Oxford University Press, 2007). 
policies and politics during the First World War. ${ }^{41}$ His essay ("Why fight a Third Balkan War? The Habsburg mindset in 1914") emphatically brushes aside any war guilt debate: "The Habsburgs did, in fact, start the Great War." And he cautions against assumptions that Austria-Hungary went to war because of the internal problems in its "southern provinces" since, as he points out, no revolutionary situation existed and the politicians in Bosnia "simply hedged their bets."

What Höbelt explores here is mainly the reasoning behind Vienna's decision for war in 1914 - as opposed to some earlier date when the circumstances might have been more favourable. Timing rather than motivation is what interests him. Nevertheless, he does address the question of why Austria-Hungary, a Great Power, should "feel threatened by a midget like Serbia". And while he stresses that Serbia in itself posed no "real threat", he reminds that what the Habsburg elite viewed with horror was the prospect of Serbia spearheading "a new League of aggressive Balkan states." All of which, incidentally, is scarcely in harmony with Cornwall's thesis of the South Slav question as "a major cause" of the war. Höbelt thus identifies the real provenance of the war: the Balkans as the playing field for the maintenance of Austria-Hungary's Great Power status. Austria-Hungary, he writes, "was a Balkan state, its Great Power position at least partly dependent on its position in the Balkans". As for the timing, Höbelt scrutinizes two major determinants. One was the Habsburgs' diplomatic fiasco during the Balkan wars, 1912-1913, which left its two potential allies in the region, Romania and Bulgaria, resentful and suspicious towards Vienna. By 1914, the "dirty work" in the Balkans would have to be done by the Monarchy itself. The other one was in fact financial. The mobilizations of the army during those wars proved a huge burden on Austria-Hungary's resources. They had cost the Austrians "more than the whole dreadnought squadron they had ordered to impress the Italians." Continuing to contain Serbia in this fashion would have severely weakened Vienna's ability to confront, say, Russia. The assassination in Sarajevo brought a new Balkan crisis, and the decision was taken to go to war "rather than go through the motions of all the pointless 1912-13 manoeuvres again."

Franz Ferdinand, the target of that assassination, is the subject of a further admirable essay in this collection: "Franz Ferdinand: Power and image", by Alma Hannig, of the University of Bonn. In 2013 Hannig published an insightful and finely balanced biography of the Archduke, one that will

41 Lothar Höbelt, „Stehen oder Fallen”: Österreichische Politik im Ersten Weltkrieg, (Wien-Köln-Weimar: Böhlau Verlag, 2015). 
surely become a standard work. ${ }^{42}$ In it, she rejects the claims that he had seriously planned to reform the Monarchy in the trialist sense. Long after such plans had been put ad acta, he merely allowed the trialist noises to be aired in public as a means of blackmailing the Hungarians. ${ }^{43}$ Most importantly, Hannig's biography deals decisively with the pronouncements repeated ad nauseam to the effect that Franz Ferdinand was a "Prince of Peace" (Friedensfürst) whose murder removed the only man capable of securing peace in 1914. "It is amazing", she writes, "that no one has so far knocked down this myth." For there exists sufficient evidence that Franz Ferdinand was "no convinced pacifist" and that he considered war as a "definitely legitimate means of politics". ${ }^{44}$

Here, Hannig's essay focuses mostly on the impressive structure of power and influence that Franz Ferdinand managed to build as heir apparent through his famous military chancellery at Belvedere. But the essay also delves into the domestic and foreign policy aspects of his plans and actions. With regard to his future schemes for the Empire, Hannig considers that he intended to secure equal rights for all the nationalities of the Monarchy, but that this was really in order to break Magyar hegemony in Hungary. She underlines the Archduke's "general disdain for parliaments, democracy and universal male suffrage." Inclined towards autocratic rule, he relied on the old feudal structures and a strong army, thus failing, like many in the Habsburg elite, to "recognize the signs of the times". In external affairs, Hannig illustrates how Franz Ferdinand had succeeded in building something of a power base through his personal contacts with foreign rulers such as the Romanian King Carol, and especially through his warm friendship with the German Kaiser, Wilhelm II. Nevertheless, she also points out that his animosity towards some foreign countries (such as republican France) and some heads of state (especially Ferdinand of Bulgaria) was "not only irrational but dangerous and blinkered." In the concluding section, Hannig cannot resist to state that, for all his networks, it "remains an open question" whether Franz Ferdinand would have had a guaranteed smooth transition following the death of Franz Joseph.

The essays by Höbelt and Hannig provide no evidence whatsoever in support of Cornwall's unproven assertion about the South Slav question being "a major cause" of the war. True, Okey's essay correctly identifies the Yugoslav ideology as one of the impulses in the evolution of Young

42 Alma Hannig, Franz Ferdinand. Die Biografie, (Wien: Amalthea Signum Verlag, 2013).

43 Ibid., 101.

44 Ibid., 172. 
Bosnia. But this was no factor at all in Habsburg calculations after 28 June. Höbelt's conclusion that in 1914 Vienna saw the political situation in Bosnia as stable does not leave much room for proclaiming the Southern Slav issues as preliminaries for war. In June-July 1914 the decision makers in Austria-Hungary were obsessed by the vision of a Russian-backed Serbia heading an alliance of Balkan states, and not by any threat connected with Yugoslav matters. The famous Matscheko memorandum illustrates fully the dread felt in Vienna about what it perceived as its rapidly deteriorating regional position. Its discussion of Serbia merely concludes that it stood fully under Russian influence. The main weight of its analysis, however, focuses on the likely re-orientation of Romania towards Russia. The jitters in Vienna did not relate to some kind of domestic, South Slav movement aiding Serbia's expansionism, but rather to what diplomats interpreted as hostile Russian (and French) activities in the Balkans.

Some scholars still ignore such evidence. T. G. Otte, another of Cornwall's contributors, writes that Vienna's fear of unchecked Serb nationalism accelerating "the centrifugal forces within the empire" was a powerful stimulant in the July crisis. Except that the relevant documents do not paint such a picture. They show compellingly that in July 1914 Austria-Hungary saw Russia as its chief enemy in the Balkans, not Serbia. Countries such as Serbia, Romania and Bulgaria were seen purely as elements in the wider regional game of the Great Powers. Otte himself more or less admits this: "Geography made Serbia a vital piece in the international jigsaw, especially so in the event of the complete crumbling of Ottoman power and the further decline of Austria-Hungary." Otte may well be right in describing the conduct of Austria-Hungary as being more akin to a "greater regional power" than that of a European Great Power. Of course, unlike the other European Great Powers, including Italy, Austria-Hungary's space for manoeuvre only extended to its immediate neighbourhood in the south-east. But its rivals there were still the Great Powers of Europe: Russia, France and Italy.

Professor Otte, however, is justly seen as one of the world's leading experts on the July crisis. ${ }^{45}$ His essay here ("Six powers appalled by war: The July crisis and the limits of crisis management") demonstrates rather convincingly that in the weeks after Sarajevo the European diplomats operated within a framework of action that had been considerably reduced since the previous crises. This was true especially as regards Germany's

45 See: T. G. Otte, July Crisis: The World's Descent into War, Summer 1914, (Cambridge: Cambridge University Press, 2014). 
relationship with its declining ally Austria-Hungary, since by July 1914 the former could not allow to let the latter become further weakened. Similarly, France was determined to preserve its alliance with Russia and uphold it against Germany, giving it in July what came close to a French version of Berlin's "blank cheque" to Vienna. Of all these powers, however, "Austria-Hungary alone was intent on war after Sarajevo." To Otte's valid points this reviewer would add another critical element in the explosive equation: after the annexation fiasco of 1908-1909, Russia could not afford another humiliation without abdicating its position as a Great Power. And Otte is entirely right in pointing out the decay of Austria-Hungary as the harbinger of trouble for the continent of Europe: "How to manage the process of the Austro-Hungarian succession was one of the unsolved questions of Great Power politics on the eve of the war."

Reasons of space prevent a review of the remaining essays in Cornwall's collection. They are in any case of marginal interest in the context of either the South Slav question or the much wider terrain of the origins of the First World War. As with most such collections, some of the essays stand out while others are quickly forgotten. But only experts are likely to profit from reading some of them. Overall, this is not suitable learning material for Cornwall's "students and general readers". Especially not the latter. What are they to make, for example, of Andrej Rahten's claim that Franz Ferdinand was murdered on account of his support for trialism when another contributor, Danilo Šarenac, informs them that the Archduke was not meant to be killed at all? Some might conclude that the study of history is a waste of time. It is to be hoped that most will view the reconstruction of bygone events as perhaps not easy, but nevertheless preferable to paying no attention to them.

\section{Summary}

The enduring interest of the historical profession in the immediate origins of the First World War is demonstrated yet again in this collection of essays edited by Mark Cornwall. Thus the Sarajevo assassination, the event that "sparked" the conflict, figures prominently as the ineluctable reference point for several essays analysing the wider issues involved. Mark Cornwall places it in the context of the Southern Slav question which 
he considers to have been "a major cause" of the war. This thesis, however, remains unproven. In laying a heavy emphasis on Serbia as an existential threat to Austria-Hungary, Cornwall fails to take into account the serious regional problems that the Empire was facing in the Balkans by the early summer of 1914, a situation that threatened its Great Power status. He is also unable to substantiate the presumption that Serbia was actively pursuing a policy aimed at amputating parts of Austria-Hungary. Lothar Höbelt, a contributor to this volume, by contrast argues that Vienna's decision for war was not in consequence of any problems in the southern provinces. He sees the Balkans as the arena in which Austria-Hungary was determined to maintain its Great Power position. Andrej Rahten, like Cornwall, concentrates on the Southern Slav question, his focus being on the "trialist" reform plans supposedly championed by Archduke Franz Ferdinand and his advisers. Those plans, envisaging the creation of a third, Croatian-led Southern Slav unit within the Empire, were according to Rahten seen in Serbia as a major danger. Rahten further suggests that the Sarajevo assassination should be understood in the context of this perception. But Rahten's arguments are deeply flawed. The evidence that he produces to show Franz Ferdinand's support for trialism turns out to emanate from a demonstrably untrustworthy source. Moreover, he attributes to Dragutin Dimitrijević Apis himself a statement expressing disquiet about the Archduke's trialist reform plans, ostensibly made by the former after the Sarajevo assassination. On closer inspection, however, the statement in question is revealed as a speculative comment made decades later by Apis's nephew Milan Živanović. The essay by Danilo Šarenac purportedly deals with Serbian military intelligence and the Sarajevo assassination, though its main themes have in fact little or nothing to do with the assassination itself. These cover Serbia's internal politics and crises after the 1903 coup, with particular emphasis on civil-military relations and the Serbian military intelligence network. Only towards the very end of his essay does Šarenac venture to hypothesize that Apis had organized the assassination, not in order for it to succeed, but rather to create a diplomatic problem with Austria for his enemy the Prime Minister Pašić.

\section{Sources and Literature}

Arhiv SANU. Zaostavština Milana Ž. Živanovića: 4019, „Rad organizacije Ujedinjenje ili Smrt“; 719, „Konflikt 1914. godine“. 
- $\quad$ Aichelburg, Wladimir. Erzherzog Franz Ferdinand von Österreich-Este 18631914: Notizen zu einem ungewöhnlichen Tagebuch eines außergewöhnlichen Lebens. Wien: Verlag Berger Horn, 2014.

- $\quad$ Albertini, Luigi. The Origins of the War of 1914, Vol. 2. London: Oxford University Press, 1952.

- Bakić,Jovo.Ideologijejugoslovenstvaizmeđusrpskogi hrvatskognacionalizma 1918-1941. Zrenjanin: Gradska narodna biblioteka „Žarko Zrenjanin“, 2004.

- Bataković, Dušan T. "Storm over Serbia: The Rivalry between Civilian and Military Authorities (1911-1914)“. Balcanica (Belgrade), vol. 44, 2013. doi: 10.2298/BALC1344307B

- $\quad$ Bjelajac, Mile. 1914-2014: Zašto revizija? Novi Sad: Prometej, 2019.

- Clark, Christopher. The Sleepwalkers: How Europe Went to War in 1914. London: Allen Lane, 2012.

- Clark, Christopher. "The Balkan Inception Scenario: Serbia and the Coming of War in 1914". Bid for World Power? New Research on the Outbreak of the First World War, eds. Andreas Gestrich, Hartmut Pogge von Strandmann. Oxford: Oxford University Press, 2017.

- Cornwall, Mark. "Between the Wars: King Nikola of Montenegro and the Great Powers, August 1913 - August 1914". The South Slav Journal (London): Part I, Spring-Summer 1986, Vol. 9, No. 1-2; Part II, Autumn-Winter 1986, Vol. 9, No. 3-4; Part III, Spring 1987, Vol. 10, No. 1.

- $\quad$ Cornwall, Mark. “Introduction” to: Andrej Mitrović. Serbia's Great War, 19141918. London: Hurst \& Company, 2007.

- $\quad$ Cornwall, Mark. “Serbia”. Decisions for War 1914, ed. Keith Wilson. New York: St. Martin's Press, 1995.

- $\quad$ Cvijić, Yovan. The Annexation of Bosnia and Herzegovina and the Serb Problem. London: Horace Cox, 1909.

- $\quad$ Dedijer, Vladimir. Sarajevo 1914, Vol. 2. Beograd: Prosveta, 1978.

- $\quad$ Dedijer, Vladimir. The Road to Sarajevo. London: MacGibbon \& Kee, 1967.

- Djordjevic, Dimitrije. "The Idea of Yugoslav Unity in the Nineteenth Century". The Creation of Yugoslavia 1914-1918, ed. Dimitrije Djordjevic. Santa Barbara and Oxford: Clio books, 1980.

- Drašković, Radovan M. Pretorijanske težnje u Srbiji. Apis i „Crna ruka“. Beograd: Žagor, 2006.

- $\quad$ Fabijančić, Tony. In the Footsteps of Gavrilo Princip. Edmonton: The University of Alberta Press, 2010.

- Franz, Georg. Erzherzog Franz Ferdinand und die Pläne zur Reform der Habsburger Monarchie. Brünn-München-Wien: Rudolf M. Rohrer, 1943.

- Hannig, Alma. Franz Ferdinand. Die Biografie. Wien: Amalthea Signum Verlag, 2013.

- Höbelt, Lothar. „Stehen oder Fallen”: Österreichische Politik im Ersten Weltkrieg. Wien-Köln-Weimar: Böhlau Verlag, 2015. 
- $\quad$ Holler, Gerd. Franz Ferdinand von Österreich-Este. Wien-Heidelberg: Verlag Carl Ueberreuter, 1982.

- Horvath, E. v. So starb der Friede, Unbekanntes über die Entstehung des Weltkrieges. Berlin: Brückenverlag, 1930.

- Janković, Dragoslav. Srbija i jugoslovensko pitanje 1914-1915. godine. Beograd: Institut za savremenu istoriju, 1973.

- $\quad$ Kiszling, Rudolf. Erzherzog Franz Ferdinand von Österreich-Este. Leben, Pläne und Wirken am Schicksalsweg der Donaumonarchie. Graz-Köln: Böhlau, 1953.

- $\quad$ MacKenzie, David. Apis: The Congenial Conspirator. Boulder: East European Monographs, 1989.

- Nešković, Borivoje. Istina o solunskom procesu. Beograd: Narodna knjiga, 1953.

- $\quad$ Okey, Robin. Taming Balkan Nationalism: The Habsburg 'Civilizing Mission' in Bosnia, 1878-1914. Oxford: Oxford University Press, 2007.

- $\quad$ Otte, T. G. July Crisis: The World's Descent into War, Summer 1914. Cambridge: Cambridge University Press, 2014.

- $\quad$ Rahten, Andrej.Jugoslovanska velika noč: Slovenski pogledi na balkanski vojni (1912-1913) in jugoslovansko vprašanje. Ljubljana: GV Založba, 2012.

- $\quad$ Rahten, Andrej. Prestolonaslednikova smrt: po sledeh slovenskih interpretacij sarajevskega atentata. Ljubljana: Cankarjeva založba, 2014.

- S Šarenac, Danilo. Top, vojnik i sećanje: Prvi svetski rat i Srbija, 1914-2009. Beograd: Institut za savremenu istoriju, 2014.

- Taylor, A. J. P. The Habsburg Monarchy 1809-1918. London: Hamish Hamilton, 1948.

- $\quad$ Taylor, A. J. P. The Struggle for Mastery in Europe 1848-1918. Oxford: The Clarendon Press, 1954.

- Vučković, Vojislav J. „Unutrašnje krize Srbije i Prvi svetski rat“. Istorijski časopis, vol. 14-15, 1963-1965.

- Zametica, John. Folly and Malice: The Habsburg Empire, the Balkans and the Start of World War One. London: Shepheard-Walwyn, 2017.

- Živanović, Milan Ž. Pukovnik Apis: solunski proces hiljadu devetsto sedamnaeste. Beograd: izdanje pisca, 1955.

- $\quad$ The Times Literary Supplement

- $\quad$ Wiener Bilder 


\title{
Резиме
}

Џон Заметица

\section{Неухватљива балканска варница: 28. јун 1914, поново и вечито}

\begin{abstract}
АПстРАКт: Убиство Франца Фердинанда 28. јуна 1914. у Сарајеву још увек, оправдано, привлачи пажњу историчара као један од кључних догађаја у историји савременог света. У овом приказу разматра се неколико новијих прилога објављених у зборнику чланака посвећених тој теми. Посебно су наглашене још увек актуелне контроверзе и контрадикторна тумачења која прате ову тему.

КљУчнЕ РЕчи: Марк Корнвол, Лотар Хебелт, Андреј Рахтен, Данило Шаренац, Први светски рат, Сарајевски атентат, Драгутин Димитријевић Апис, Аустроугарска, јужнословенско питање
\end{abstract}

Дуготрајно интересовање историјске струке за непосредне узроке Првог светског рата још једном се исказује у зборнику радова који је уредио Марк Корнвол. Тако Сарајевски атентат, догађај који је „покренуо“ сукоб, фигурира као неизбежна референтна тачка у неколико чланака који анализирају шира питања. Марк Корнвол га смешта у контекст јужнословенског питања, које сматра „једним од главних узрока" рата. Међутим, ова теза остаје без доказа. Нарочито истичући Србију као егзистенцијалну претњу Аустроугарској, Корнвол не узима у обзир озбиљне регионалне проблеме са којима се царевина суочавала на Балкану до раног лета 1914. и који су угрозили њен статус велике силе. Поред тога, не успева да докаже претпоставку да је Србија активно водила политику у циљу ампутирања делова Аустроугарске. С друге стране, Лотар Хебелт, један од заступљених аутора, тврди да одлука Беча да ступи у рат није била последица било каквих проблема у јужним покрајинама. Он Балкан види као арену у којој је Аустроугарска била одлучна да задржи позицију велике силе. Андреј Рахтен се, попут Корнвола, концентрише на јужнословенско питање, а његов фокус је на „тријалистичким“ реформским плановима које су наводно заступали надвојвода Франц Фердинанд и његови саветници. Ти планови, који предвиђају стварање треће јужнословенске јединице под вођством Хрвата у оквиру 
Монархије, према Рахтену су у Србији сматрани великом претњом. Он даље наговештава да Сарајевски атентат треба схватити у контексту такве перцепције. Међутим, Рахтенови аргументи су дубоко проблематични. Испоставља се да докази које износи да би предочио подршку Франца Фердинанда тријализму потичу из очито непоузданог извора. Штавише, и самом Драгутину Димитријевићу Апису приписује изјаву, наводно изречену после Сарајевског атентата, у којој изражава забринутост због надвојводиних тријалистичких реформских планова. Пажљивијим истраживањем долазимо до податка да је та изјава заправо спекулација коју је Аписов сестрић Милан Живановић изнео неколико деценија касније. Чланак Данила Шаренца наизглед се бави српском војном обавештајном службом и Сарајевским атентатом, иако његове главне теме заправо имају врло мало или немају нимало везе са самим атентатом. У те теме спадају унутрашња политика Србије и кризе након преврата 1903, са посебним нагласком на цивилно-војним односима и српској војно-обавештајној мрежи. Тек на самом крају чланка Шаренац износи претпоставку да је Апис организовао атентат, не да би он успео, већ да би направио дипломатски проблем са Аустријом свом непријатељу - премијеру Пашићу. 